\title{
Flowable composites as alternative materials for the restoration of noncarious cervical lesions
}

\author{
Compozitele fluide ca materiale alternative de restaurare \\ a leziunilor cervicale de uzură
}

\author{
Diana Oneț (Bănuț) ${ }^{1}$, Alexandra Roman ${ }^{1}$, Petra Șurlin², Andrada Soancă ${ }^{1}$, \\ Ada Delean ${ }^{3}$, Andreea Ciurea', Iulia Cristina Micu' ${ }^{1}$ \\ ${ }^{1}$ Disciplina de Parodontologie, Universitatea de Medicină și Farmacie \\ „Iuliu Hațieganu“, Cluj Napoca, România \\ ${ }^{2}$ Disciplina de Parodontologie, Universitatea de Medicină și Farmacie, Craiova, România \\ ${ }^{3}$ Disciplina de Odontologie, Endodonție și Patologie orală, Universitatea de Medicină și Farmacie \\ „Iuliu Hațieganu“, Cluj Napoca, România
}

\begin{abstract}
Noncarious cervical lesions (NCCLs) are defined by the loss of hard dental tissues localized at the cervical area of the teeth, having different etiology as compared to carious lesions. They occupy an important place in dental pathology and can be a real challenge for the specialist in terms of diagnosis and treatment plan. The management of all the etiological factors involved in their occurrence, as well as the selection of the ideal restorative materials and techniques still remain controversial topics. NCCLs have a significant negative impact on dental and periodontal health while certain histo-morphological features make both the diagnosis and treatment phases difficult. The NCCLs clinical approach involves the identification and elimination of all ethiological and risk factors involved in their occurrence and the actual restoration of lost dental tissues.

Both the characteristics of the lesion and the proximity of the periodontal tissues should be considered when choosing the working protocols and materials in order to maintain the periodontal health. The behaviour and specific features of composite materials derive from their composition and structure. Their major disadvantage is the polymerization shrinkage, which negatively influences the clinical performance of restorations, especially in the case of NCCLs. The aim of this article is to highlight certain important aspects regarding the properties and performance of flowable composites in restoring NCCLs.
\end{abstract}

Keywords: composite resin, restoration, retention rate, polymerization shrinkage

\section{REZUMAT}

Leziunile cervicale de uzură (LCU) reprezintă pierderi de țesut dur de la nivelul coletului dentar, de etiologie diferită de cea a leziunilor carioase. Acestea ocupă un loc important în patologia dentară și pot să reprezinte o adevărată provocare pentru medicul specialist în ceea ce priveste diagnosticul și planul de tratament. Modul de gestionare a tuturor factorilor etiologici implicați în apariția lor, precum și alegerea tehnicilor și a materialelor ideale de restaurare rămân încă subiecte controversate. LCÚ au un impact negativ important asupra sănătătii dentoparodontale și prezintă anumite particularități histo-morfologice care pun în dificultate atât faza de diagnostic, cât și cea terapeutică. Abordarea clinică a LCU presupune depistarea și eliminarea tuturor factorilor etiologici sau de risc implicați în apariția lor și restaurarea propriu-zisă a țesuturilor dentare pierdute. În alegerea protocoalelor de lucru și a materialelor utilizate, se ține cont atât de particularitățile leziunii, cât și de proximitatea și importanța menținerii sănănătii tesuturilor parodontale. Comportamentul si proprietătile materialelor compozite derivă din compoziția și structura lor, iar dezavantajul major al acestora, contracția de polimerizare, influențează negativ performanța clinică a restaurărilor, cu precădere în cazul LCU. Scopul acestui articol este de a sublinia anumite aspecte importante cu privire la proprietățile și performanța rășinilor compozite fluide ca materiale de restaurare a LCU.

Cuvinte cheie: rășină compozită, restaurare, rată de retenție, contracție de polimerizare 


\section{INTRODUCERE}

Leziunile cervicale de uzură (LCU) sunt frecvent întâlnite în patologia dentară și au un impact important asupra esteticii și funcționalității unităților dentare afectate.

Literatura și studiile de specialitate oferă informații puține și contradictorii cu privire la protocolul terapeutic sau alegerea unui material ideal de restaurare pentru aceste leziuni. În plus, evaluarea și menținerea sănătății structurilor parodontale adiacente sunt esențiale în cadrul oricărui plan de tratament și depind atât de protocolul ales, cât și de materialele utilizate.

Studiile furnizează rezultate diferite în legătură cu prevalența LCU, cu limite cuprinse între 5\% și $85 \%$, ca urmare a varietății criteriilor de diagnostic și clasificare a acestor tip de leziuni (1). Frecvența, numărul și severitatea LCU sunt direct proporționale cu vârsta pacienților drept consecință a cumulării factorilor cauzali de-a lungul timpului, a suprasolicitării unităților dentare restante asociate edentațiilor, a modificărilor microstructurale din smalț și dentină sau a modificărilor salivare cantitative și calitative survenite în urma procesului de îmbătrânire $(1,2,3)$. S-a observat o frecvență mai mare a LCU și la adolescenți, posibil din cauza consumului crescut de băuturi acide carbogazoase la această vârstă (2).

LCU au la bază o etiologie multifactorială (4). LCU sunt consecința acțiunii cumulate a unor factori fizico-chimici asupra țesuturilor dure dentare, care duce la pierderea progresivă a acestora, cel mai frecvent dinspre exterior spre interior, în absența cariei dentare și fără implicare bacteriană $(2,5)$. Mecanismele principale care stau la baza producerii acestor leziuni includ mai ales fenomene de fricțiune (abrazie), coroziune (degradarea chimică) şi stres cumulat în zona cervicală (1).

Mecanismele abrazive de producere a LCU fac referire la igiena dentară riguroasă, realizată lungi perioade de timp, asociată cu creșterea alimentației bogate în elemente abrazive. Acțiunea forțelor abrazive asupra unor zone dentare ,slăbite“ de o disoluție chimică anterioară crește pierderea de țesuturi dentare din zona cervicală (6). În acelaşi timp, se iau în considerare și consecințele forțelor abrazive asupra țesuturilor gingivale, cu posibilitatea de inducere concomitentă a recesiilor gingivale (7).
Forțele masticatorii, îndeosebi cele de tensiune, induc mișcări de flexie a dinților în regiunea coletului, generând un stres care se acumulează cervical, ceea ce poate să producă disrupția legăturilor dintre cristalele de hidroxiapatită. Pierderea structurilor dentare fisurate în zona cervicală este accentuată de forțele abrazive sau de fenomenele de coroziune. Astfel, forțele ocluzale, mai ales cele anormale (8), pot să contribuie la pierderea de țesut dentar și la dezvoltarea LCU (9). Stresul consecutiv flexiei dintelui, generat de forțele mecanice rezultate în timpul funcționalității aparatului dento-maxilar, se concentrează şi la nivelul interfeței adezive ale restaurărilor cervicale, ceea ce poate afecta integritatea adeziunii și longevitatea restaurărilor LCU (2). Acest aspect trebuie luat în considerare în elaborarea planului de tratament al LCU.

Netratate, LCU evoluează invariabil, influențând negativ starea sănătății odonto-parodontale $(4,10)$. Etiologia multifactorială a acestor leziuni dentare impune o abordare terapeutică globală, iar tratamentul lor implică, de cele mai multe ori, o etapă clinică de restaurare a integrității și funcționalității dinților afectați, dependentă de gradul de evoluție a leziunii și simptomele asociate acesteia. În plus, se asociază eforturile de eliminare sau modificare a factorilor de risc și etiologici implicați (10).

\section{PARTICULARITĂȚI HISTO-MORFOLOGICE ALE LCU ŞI INFLUENTA ACESTORA ASUPRA SUCCESULUI TERAPEUTIC AL RESTAURĂRILOR CERVICALE}

LCU sunt localizate în regiunea cervicală a dintelui în apropierea joncțiunii amelo-cementare, o regiune foarte vulnerabilă la influențele mediului, ca urmare a stratului de smalț și cement extrem de subțiri din această zonă $(1,11)$. Aceste leziuni pot fi localizate coronar, radicular sau corono-radicular (12).

LCU se dezvoltă cel mai frecvent pe suprafațele vestibulare şi afectează mai ales premolarii $(1,13,14)$. Din punct de vedere morfologic, cele mai frecvente forme de prezentare clinică ale LCU sunt leziunile tip "wedge-shaped" și "saucershaped" (11).

LCU se asociază cu o structură aprismatică a smalțului sănătos restant în treimea cervicală, mai 
puțin mineralizat și mai rezistent la gravarea acidă $(1,15,16)$. Direcția prismelor de smalț în această regiune este modificată, rezultând o suprafață de contact aplatizată între smalț și dentină, ceea ce diminuează conexiunea mecanică dintre cele două substraturi (1).

Legătura adezivă dentinară a compozitelor la nivelul pragului gingival al cavităţilor este mai slabă decât la nivelul celorlalte zone (17) din cauza demineralizării și penetrării adezive mai reduse la acest nivel (18). Acest lucru se datorează faptului că dentina cervicală este mai puțin mineralizată decât dentina situată mai coronar, iar densitatea tubilor dentinari este mai mare. Astfel, ar fi de aşteptat ca demineralizarea în zona pragului gingival să fie mai rapidă. Totuși, creșterea umidității în zona dentinei pragului gingival, ca o consecință a unui eflux crescut de lichid dentinar, ar putea reduce infiltrarea adezivului și interfera polimerizare în zona gingivală (18).

În plus, există anumite diferențe histologice între dentina sănătoasă şi cea sclerotică noncarioasă, ceea ce influențează major calitatea interfeței adezive (19). Dentina asociată LCU devine sclerotică, iar canaliculii dentinari pot fi obliterați parțial sau total de depozitele sclerotice $(19,20,21)$, ceea ce poate altera substratul de adeziune și diminua retenția restaurărilor.

$\mathrm{Nu}$ în ultimul rând, au fost descrise alterări ale compoziţiei şi microstructurii smalţului și dentinei consecutive procesului de îmbătrânire (6), ceea ce induce o variabilitate histologică și mai mare a LCU.

Succesul clinic al restaurărilor LCU este influențat, într-o mare măsură, atât de caracteristicile histologice și morfologice ale țesuturilor dure restante, cât și de relația acestora cu structurile parodontale. De asemenea, succesul clinic al restaurărilor LCU depinde, în mare parte, şi de materialul și tehnica de restaurare alese. Conform studiilor actuale și literaturii, cea mai mare problemă a restaurărilor LCU este retenția redusă, care duce la pierderea frecventă a acestora și, implicit, la eșec terapeutic (5).

\section{RĂŞINI COMPOZITE FLUIDE VS. RĂŞINI COMPOZITE CONVENȚIONALE: COMPOZIȚIE ŞI PROPRIETĂṬI}

Materialele pentru restaurarea directă a LCU trebuie să posede proprietăți care să le asigure o integritate mecanică şi adeziune optime pentru funcționalitatea și supraviețuirea îndelungată în mediul oral, la fel ca și dinții naturali (22).

Rășinile compozite au fost introduse pe piață ca materiale de restaurare pentru zonele anterioare, ulterior, fiind tot mai frecvent utilizate și în zonele posterioare, ca alternativă mai estetică și mai conservativă a amalgamului (23). Evoluția substanțială de-a lungul timpului a dus la apariţia compozitelor de tip hibrid, cu nanoumplutură, microumplutură, condensabile sau fluide (24), ceea ce a dus la extinderea considerabilă a paletei de utilizare clinică. Pentru restaurările cervicale, materiale compozite au devenit o alternativă mai populară la cimenturile glassionomere datorită proprietăților estetice și mecanice superioare, precum și manipulării mult simplificate (25). Există o gamă largă de rășini compozite utilizate pentru restaurări directe ale LCU, care se diferenţiază prin gradul de vâscozitate, compoziție, proprietăţi și indicații de utilizare. Compozitele convenționale hibride sunt cele mai utilizate la ora actuală, având indicații clinice multiple. Pe de altă parte, compozitele fluide au fost introduse pe piața materialelor dentare în scopul de a pune la dispoziția medicilor stomatologi un material cu proprietăți ameliorate față de compozitele convenționale, care să permită utilizarea lor în anumite situații clinice (26).

Compozitele convenționale prezintă rezistență crescută la uzură și umiditate, estetică excelentă și stabilitate a culorii în timp (15). Retenția restaurărilor obținută prin utilizarea sistemelor adezive asociate permite o adeziune bună la structurile dentare și conservarea țesuturilor, ceea ce coincide cu conceptul de stomatologie minimum invazivă caracteristică tratamentelor stomatologice actuale (27).

Calitatea și cantitatea umpluturii anorganice din compoziția materialelor compozite dictează în mod esențial atât proprietățile mecanice ale acestor materiale, cât și alte caracteristici ale acestora. Astfel, sticlele de bariu și stronţiu se includ pentru a se integra în rețeaua de silică pentru creșterea radioopacității materialelor (10). De asemenea, aceste sticle de bariu și stronțiu au un indice de refracție mai mare decât silica și, astfel, modifică indicele de refracție al particulelor de umplutură, crescând transparența compozitelor, ceea ce îmbunătățește estetica fără a altera proprietățile mecanice ale materialelor (28). Fluorura de yterbiu 
se poate adăuga ca agent de creștere a radioopacității (29).

Compozitele convenționale hibride prezintă o încărcătură de umplutură care ocupă 50-70\% din volum, față de compozitele fluide, pentru care umplutura anorganică este redusă, ajungând la un procent de $37-53 \%$ din volumul total (24). Cantitatea de umplutură influențează proprietățile materialelor compozite, mai ales în ceea ce privește vâscozitatea, modulul de elasticitate și contracția de priză a acestora (30).

Vâscozitatea compozitelor scade în urma reducerii gradului de umplutură, ceea ce induce manipularea mult simplificată a compozitelor fluide față de compozitele convenționale (31). De asemenea, vâscozitatea redusă asigură o umectabilitate crescută și adaptarea superioară a materialului la pereții interni ai cavităților $(26,32)$.

Modulul de elasticitate al compozitelor este direct proporțional cu cantitatea particulelor de umplutură $(30,33)$, astfel încât proporţia crescută acestora se asociază cu un modul de elasticitate crescut și rezistență crescută la deformare în cazul compozitelor convenţionale hibride (30). Modulul de elasticitate mai redus al compozitelor fluide față de cele convenționale eliberează o parte din stresul generat la polimerizare sau în timpul funcțiilor, ceea ce reprezintă un avantaj exploatat pentru restaurarea LCU (34).

Rigiditatea materialului este o proprietate a materialelor care influențează major supraviețuirea legăturii adezive și, implicit, a restaurărilor compozite și care este dependentă de modulul de elasticitate. Compozitele convenționale având un modul de elasticitate crescut sunt rigide, în timp ce compozitele fluide prezintă o oarecare elasticitate, fiind, astfel, mai puţin susceptibile fracturilor datorate stresului cumulat în regiunea cervicală în timpul reacției de polimerizare și în timpul funcționalităţii (15).

Proprietățile adezive ale materialelor compozite impactează major stabilitatea restauraţiilor și consecințele biologice asupra structurilor dentare și parodontale (35). Adeziunea compozitelor este un fenomen complex care depinde nu numai de capacitățile adezive intrinseci ale materialelor, dar și de priza acestora, sistemul adeziv asociat, precizia protocolului clinic de aplicare (21), posibilitatea de control al umidităţii locale (36) și de tipul și calitatea substratului dentar $(6,37)$.
Calitatea elementelor componente ale rășinilor compozite este responsabilă de comportamentul și capacitatea adezivă a acestora, deși microinfiltrația marginală a restaurărilor compozite depinde și de calitatea substratului dentar. De asemenea, materialele compozite sunt adesea investigate convențional, pentru testarea proprietăţilor adezive, dar, recent, au fost propuse investigații suplimentare pentru determinarea detaliilor specifice legate de adeziune și structura materialelor, precum analiza prin microscopie electronică de baleiaj (38).

În afara calităților anterior menționate, există anumite inconveniente încă nesoluționate ale rășinilor compozite, care pot afecta performanța clinică și longevitatea restaurărilor dentare (36). Cel mai important deficit al rășinilor compozite este contracția de polimerizare, care poate produce o rupere a interfeței adezive între material şi suprafața dentară și o microinfiltrație consecutivă, cu toate consecințele sale: decolorare marginală, hipersensibilitate postterapeutică, carii secundare și patologie pulpară și gingivală $(15,16,23)$. Microinfiltraţia este definită ca un pasaj al bacteriilor, fluidelor, moleculelor sau ionilor între pereții cavității și materialul de restaurare (39), ca urmare a adaptării marginale deficitare. Valoarea contracției de polimerizare variază între $1,35 \%$ și $7,1 \%$, fiind semnificativ mai mare pentru răşinile cu conţinut de monomeri de tip Bis-GMA și TEGDMA și pentru răşinile fluide comparativ cu cele convenționale, hibride sau cu microumplutură (40). Prin urmare, amplitudinea contracției care însoțește reacția de polimerizare depinde de compoziția materialului, mai exact, de forma și dimensiunea particulelor de umplutură, de cantitatea şi tipul de monomeri incluşi sau de tipul matricii organice. Nu în ultimul rând, contracția de polimerizare este influențată și de factori tehnici, cum ar fi intensitatea luminoasă a lămpii de polimerizare, grosimea stratului de material raportată la profunzimea cavității și tehnica de realizare a restaurării (41).

Compozitele convenționale hibride au o contracție de polimerizare de 2,5-3,5\% (33). Compozitele fluide în contrast cu compozitele convenționale hibride au o contracție de polimerizare crescută $(31,33)$. Majoritatea compozitelor fluide au o contracție de polimerizare de aproximativ $5 \%$, în mare parte datorată conținutului anorganic redus (33). 
Pentru menținerea proprietăților la standardele dorite, unele compozite fluide mențin un conținut ridicat de încărcătură anorganică, dar prezintă adaos de agenţi tensioactivi pentru ameliorarea fluidităţii. Astfel, Gaenial Flow ${ }^{\circledR}$-GC are un continut anorganic de $69 \%$ greutate (50\% volum) (42). Gaenial Flow ${ }^{\circledR}$ are o contracție de polimerizare de 3,4\%, dar un stres generat de polimerizare asemănător celorlalte compozite fluide (42).

Microinfiltrația a fost citată ca fiind o cauză importantă de eșec al restaurărilor LCU (39), posibil pentru că marginile cervicale ale acestor leziuni sunt localizate adesea în cement sau dentină, iar adaptarea și adeziunea restaurărilor compozite la aceste țesuturi sunt mai puțin predictibile și mult inferioare adeziunii la smalț $(23,39)$. Deoarece, în majoritatea situațiilor, marginea coronară a restaurărilor LCU este localizată în smalț și marginea cervicală este localizată în dentină sau cement, microinfiltrația este prezentă, de obicei, la nivel cervical și poate periclita interfața adezivă și performanța clinică a restaurărilor (39).

Contracția de polimerizare a compozitelor este un subiect încă cercetat, însă asocierea ei cu aceste materiale este mai degrabă o regulă decât o excepție (23).

Un alt inconvenient important al materialelor compozite, cu impact major asupra sănătății parodontale, este citotoxicitatea acestora. În acest sens, răşinile compozite pot exercita efecte nocive locale datorate monomerilor toxici nereacționați în urma reacției de polimerizare și eliberați treptat prin degradarea progresivă a materialului $(43,44)$. La nivel celular, s-au descris efecte citotoxice, mutagene și genotoxice $(45,46,47)$, iar, din punct de vedere clinic, aceste efecte se manifestă prin inflamație gingivală și pierdere de ataşament (48).

Informațiile disponibile cu privire la efectul toxic al compozitelor asupra componentelor parodontale sunt inconstante $(49,50)$. În plus, există studii care susțin faptul că rășinile compozite fluide produc o toxicitate celulară superioară altor tipuri de răşini compozite, prin eliberarea unor cantități mai mari de monomeri BisGMA sau TEGDMA (51) și prezența unor cantități mai mari de diluanți de rășină în compoziție, necesari pentru obținerea fluidității (52). Frecvența crescută a utilizării compozitelor în practică și importanța sănătății parodontale impun efectuarea unor cercetări suplimentare cu privire la acest subiect.

\section{RĂŞINI COMPOZITE FLUIDE CA MATERIALE DE RESTAURARE A LCU}

Managementul LCU reprezintă o provocare pentru medicul dentist, iar restaurarea componentei coronare este esențială pentru stoparea progresiei leziunii, prevenirea sau eliminarea hipersensibilităţii dentinare și prevenirea apariției cariilor cervicale, a fracturilor dentare sau a afectiunilor pulpare (2). În plus, realizarea unei restaurări LCU corespunzătoare împiedică retenția de placă în zona dentară cervicală și, implicit, apariția inflamației gingivale, atât timp cât igiena pacientului este optimă. Deoarece LCU se găsesc frecvent în zone cu importanță estetică deosebită, restaurarea acestora trebuie să se încadreze perfect în armonia arcadelor dentare și să redea aspectul estetic cât mai natural.

Restaurarea LCU reprezintă încă o provocare pentru clinician din cauza anatomiei leziunilor, concentrării stresului ocluzal în zona cervicală, prezenței dentinei sclerotice care alterează adeziunea materialului la substrat (5) și dificultăților de izolare a zonelor implicate (36). În plus, trebuie luate în considerare cerințele pacienților, costurile, necesitatea preparării cavității și tehnica utilizată. Comportamentul și longevitatea restaurărilor LCU sunt influențate atât de particularitățile leziunii, cât și de factorii care țin de pacient (ocluzie, parafuncții, obiceiuri vicioase, bruxism, dietă erozivă) și de protocolul de lucru (tipul de material și sistem adeziv, tehnica de restaurare, modalitatea de izolare a zonei și experiența practicianului) (15).

$\mathrm{Cu}$ toată oferta largă de materiale de restaurare și unele recomandări recente ale literaturii, la ora actuală încă există controverse cu privire la materialul ideal pentru restaurarea LCU (11). În prezent, cele mai recomandate materiale pentru acest tip de leziuni sunt rășinile compozite, compomerii şi glass-ionomerii convenționali sau modificați cu rășini $(21,39,53)$ datorită proprietăților estetice și mecanice superioare altor materiale $(2,5)$. Compozitele fluide sunt utilizate în multe situații clinice, iar folosirea lor pentru restaurarea cavităților de clasa a-V-a se extinde tot mai mult în practica clinică (30). Modulul de elasticitate scăzut asociat compozitelor fluide le recomandă în restaurarea LCU, deoarece le permite mișcarea de flexie împreună cu dintele, ceea ce poate îmbunătăti performanța clinică a restaurațiilor LCU, absor- 
bind o parte din stresul acumulat la nivelul interfeței adezive în timpul funcțiilor (54). Asocierea compozitelor fluide cu compozitele clasice pentru restaurarea unor LCU de dimensiuni mai mari poate îmbunătăţi calitatea interfeței adezive $(15,30)$. Ca urmare a rigidității și a modulului de elasticitate crescut, compozitele convenționale nu sunt capabile să compenseze stresul produs prin contracția materialului în timpul reacției de polimerizare, ceea ce poate duce la fracturi ale țesuturilor dentare, microinfiltrație, sensibilitate postoperatorie și alterarea legăturii adezive (30).

Totuşi, contracția crescută de polimerizare şi riscul de flexie a restaurării susținute de un compozit cu modul de elasticitate scăzut pot avea efecte negative încă incomplet cunoscute asupra succesului clinic (30).

În ceea ce privește manipularea și tehnica de inserție, compozitele fluide se aplică cu ușurință datorită vâscozităţii reduse, iar adaptarea acestora la pereții interni ai cavităţilor este superioară altor tipuri de rășini compozite (30). Consistența scăzută a compozitelor fluide și posibilitatea aplicării acestora prin tehnica de injectare permit utilizarea lor în zone greu accesibile.

$\mathrm{Cu}$ toate acestea, compozitele fluide prezintă anumite dezavantaje, dintre care cele mai importante sunt rezistența redusă la uzură și contracția crescută de polimerizare, ambele datorate în mare parte cantității reduse de umplutură, necesară însă pentru obținerea consistenței fluide și manipularea facilă a materialului. Aceste inconveniente limitează astfel indicațiile clinice ale compozitelor fluide, acestea fiind utilizate cu precădere în zonele

\section{BIBLIOGRAFIE}

1. Kolak V, Pešić D, Melih I, Lalović M, Nikitović A, Jakovljević A. Epidemiological investigation of non-carious cervical lesions and possible etiological factors. J Clin Exp Dent. 2018;10(7):e648-56.

2. Celik EU, Tunac AT, Yilmaz F. Three-year clinical evaluation of high-viscosity glass ionomer restorations in non-carious cervical lesions: a randomised controlled split-mouth clinical trial. Clin Oral Investig. 2019;23(3):1473-80.

3. Yoshizaki KT, Francisconi-dos-Rios LF, Sobral MAP, Aranha ACC, Mendes FM, Scaramucci T. Clinical features and factors associated with non-carious cervical lesions and dentin hypersensitivity. J Oral Rehabil. 2017;44(2):112-8.

4. Nascimento MM, Dilbone DA, Pereira PNR, Duarte WR, Geraldeli S, Delgado AJ. Abfraction lesions: Etiology, diagnosis, and treatment options. Vol. 8. Clinical, Cosmetic and Investigational Dentistry. Dove Medical Press Ltd. 2016;79-87.

5. Bezerra IM, Brito ACM, de Sousa SA, Santiago BM, Cavalcanti YW, de Almeida $L$ de FD. Glass ionomer cements compared with cu stres ocluzal redus $(24,30)$ și în cavități de mici dimensiuni $(15,24)$.

\section{CONCLUZII}

La ora actuală, piaţa materialelor dentare oferă o gamă vastă și variată de materiale de restaurare, ale căror indicații de utilizare au la bază principalele lor caracteristici. Tehnicile, materialele și protocoalele de restaurare trebuie adaptate constant la cerințele actuale, care diferă major de la caz la caz. Alegerea celui mai bun material de restaurare pentru o anumită situație clinică trebuie individualizată și realizată în funcție de particularitățile fiecărui caz clinic.

Materialele compozite se prezintă sub numeroase variante comerciale, care diferă prin compoziție și proprietăţi, fiind preferate de către practicieni în majoritatea situațiilor clinice datorită calităților superioare altor tipuri de materiale de restaurare.

$\mathrm{Ca}$ urmare a manipulării simplificate și a flexibilităţii crescute, compozitele fluide reprezintă o variantă bună pentru restaurarea LCU. Proprietăţile mecanice inferioare ale compozitelor fluide limitează utilizarea lor, dar supraviețuirea restaurărilor LCU pe termen lung este încă un subiect de cercetare.

\section{Notă}

Această lucrare a fost realizată în cadrul Proiectului de Cercetare Doctorală susţinut de Universitatea de Medicină și Farmacie „Iuliu Haţieganu“, Cluj-Napoca. Nr. contract 2462/8/17 ianuarie 2020 .

Conflict of interest: none declared Financial support: none declared

composite resin in restoration of noncarious cervical lesions: A systematic review and meta-analysis. Heliyon. 2020;6(5):e03969.

6. Lai ZY, Zhi QH, Zhou Y, Lin HC. Prevalence of non-carious cervical lesions and associated risk indicators in middle-aged and elderly populations in Southern China. Chin J Dent Res. 2015;18(1):41-50.

7. Heasman PA, Holliday R, Bryant A, Preshaw PM. Evidence for the occurrence of gingival recession and non-carious cervical lesions as a consequence of traumatic toothbrushing. Journal of Clinical Periodontology. 2015;42(S16):S237-55.

8. Pintado MR, Delong R, Ko CC, Sakaguchi RL, Douglas WH. Correlation of noncarious cervical lesion size and occlusal wear in a single adult over a 14-year time span. J Prosthet Dent. 2000; 84(4):436-43.

9. Rees JS. A review of the biomechanics of abfraction. Eur J Prosthodontics Restorative Dentistry. 2000;8(4):139-44.

10. Grippo JO. Noncarious Cervical Lesions: The Decision to Ignore or Restore. Journal of Esthetic Dentistry 1992;4(Suppl.):55-64. 
11. Ruan JY, Gong ZL, Zhang RZ, Zhang Z, Xu R, Li DX, et al. Evaluation of four different restorative materials for restoration of the periodontal condition of wedge-shaped defect: A comparative study. Med Sci Monit. 2017;23:4462-70.

12. Zucchelli G, Gori G, Mele M, Stefanini M, Mazzotti C, Marzadori M, et al. Non-Carious Cervical Lesions Associated With Gingival Recessions: A Decision-Making Process. J Periodontol. 2011; 82(12):1713-24.

13. Borcic J, Anic I, Urek MM, Ferreri S. The prevalence of non-carious cervical lesions in permanent dentition. J Oral Rehabil. 2004; 31(2):117-23.

14. Du JK, Wu JH, Chen PH, Ho PS, Chen KK. Influence of cavity depth and restoration of non-carious cervical root lesions on strain distribution from various loading sites. BMC Oral Health. 2020; 20(1):1-10.

15. Alwadai MHD. Restorative materials for non-carious cervical lesions: A review. Int J Clin Dent Sci. 2018;1:1-5

16. Chee HT, Bakar WZW, Ghani ZA, Amaechi BT. Comparison of composite resin and porcelain inlays for restoration of noncarious cervical lesions: An in vitro study. Dent Res J (Isfahan). 2018; 15(3):215-9.

17. Purk JH, Dusevich V, Glaros AG, Spencer P, Eick JD. In vivo versus in vitro microtensile bond strength of axial versus gingival cavity preparation walls in Class II resin-based composite restorations. JADA. 2004;135:185-193.

18. Wang Y, Spencer P. Interfacial chemistry of Class II composite restoration: structure analysis. J Biomed Mater Res. 2005;75A:580-587.

19. Tay FR, Pashley DH. Resin bonding to cervical sclerotic dentin: A review. Vol. 32. Journal of Dentistry (Elsevier). 2004;173-96.

20. Daley T, Harbrow D, Kahler B, Young W. The cervical wedge-shaped lesion in teeth: a light and electron microscopic study. Aust Dent $\mathrm{J}$. 2009;54(3):212-9.

21. Perez Cdos R, Gonzalez MR, Prado NA, de Miranda MS, Macêdo Mde A, Fernandes BM. Restoration of noncarious cervical lesions: when, why, and how. Int J Dent. 2012;2012:687058.

22. Ilie N, Hilton TJ, Heintze SD, Hickel R, Watts DC, Silikas N, et al. Academy of Dental Materials guidance - Resin composites: Part I Mechanical properties. Dent Mater. 2017;33(8):880-94.

23. Rizk HM, Al-Ruthea M, Habibullah MA. The effect of three lining materials on microleakage of packable composite resin restorations in young premolars with cavity margins located on enamel and dentin/cementum - An In vitro study. Int J Health Sci (Qassim). 2018; 12(6):8-17.

24. Baroudi K, Rodrigues JC. Flowable Resin Composites: A Systematic Review and Clinical Considerations. J Clin Diagn Res. 2015; 9(6):ZE18-24

25. de Paula AM, Boing TF, Wambier LM, Hanzen TA, Loguercio AD, Armas-Vega A, et al. Clinical performance of non-carious cervical restorations restored with the "Sandwich Technique" and composite resin: A systematic review and meta-analysis. J Adhes Dent. 2019; 21(6):497-508.

26. Lee IB, Son HH, Um CM. Rheologic properties of flowable, conventional hybrid, and condensable composite resins. Dental Materials. 2003;19(4):298-307.

27. Murdoch-Kinch CA, Mc Lean ME. Minimally invasive dentistry. The Journal of the American Dental Association. 2003:134(1):87-95.

28. Habib E, Wang R, Wang Y, Zhu M, Zhu XX. Inorganic Fillers for Dental Resin Composites: Present and Future. ACS Biomater Sci Eng. 2016;2(1):1-11.

29. Watts DC. Radiopacity vs. composition of some barium and strontium glass composites. J Dent. 1987;15:38-43.

30. Attar N, Tam LE, Mccomb D. Flow, strength, stiffnes and radiopacity of Flowable Resin Composites. J Can Dent Assoc (Tor). 2003; 69(8):516-21.

31. Bayne SC. A characterization of first-generation flowable composites. Journal of American Dental Association. 1998;129:567-77.

32. Stavridakis MM, Dietschi D, Krejci I. Polymerization shrinkage of flowable resin-based restorative materials. Oper Dent. 2005; 30(1):118-28.
33. Labella R, Lambrechts P, Van Meerbeek B, Vanherle G. Polymerization shrinkage and elasticity of flowable composites and filled adhesives. Dent Mater. 1999;15(2):128-37.

34. Peumans M, De Munck J, Mine A, Van Meerbeek B. Clinical effectiveness of contemporary adhesives for the restoration of non-carious cervical lesions. A systematic review. Dent Mater. 2014; 30:1089-1103.

35. Leknes KN. The Influence of Anatomic and latrogenic Root Surface Characteristics on Bacterial Colonization and Periodontal Destruction: A Review. Journal of Periodontology. 1997;68(6):507-16.

36. Perez CR. Alternative technique for class $v$ resin composite restorations with minimum finishing/ polishing procedures. Oper Dent. 2010;35(3):375-9.

37. Zhou L, Tan J, Hu B, Feng H. Ultrastructural study of sclerotic dentin in non-carious cervical lesions disposed by a totaletching dentin adhesive. Beijing Da Xue Xue Bao. 2004;36:319-321.

38. Roman A, Stratul SI, Rusu D, Boariu M, Soanca A, Balazsi R, et al. Investigations on the adhesion of new composites for restoring cervical lesions using energy dispersive X-ray analysis and scanning electron microscopy. Sci Rep. 2019;9(1):1-10.

39. Bollu IP, Hari A, Thumu J, Velagula LD, Bolla N, Varri S, et al. Comparative evaluation of microleakage between nano-ionomer, giomer and resin modified glass ionomer cement in class $\mathrm{V}$ cavities CLSM study. J Clin Diagnostic Res. 2016;10(5):ZC66-70.

40. Langalia A, Buch A, Khamar M, Patel P. Polymerization shrinkage of composite resins: a review. J Med Dent Sci Res. 2015;2(10):23-7.

41. Braga RR, Hilton TJ, Ferracane JL. Contraction stress of flowable composite materials and their efficacy as stress-relieving layers. J Am Dent Assoc. 2003;134(6):721-8.

42. G-aenial Flowable Composite. Brochure. GC America INC. 2016.

43. Goldberg M. In vitro and in vivo studies on the toxicity of dental resin components: a review. Clin Oral Investig. 2008;12(1):1-8.

44. Van Landuyt KL, Nawrot T, Geebelen B, De Munck J, Snauwaert J, Yoshihara K, Scheers H, Godderis L, Hoet P, Van Meerbeek B. How much do resin-based dental materials release? A meta-analytical approach. Dent Mater. 2011;27(8):723-47.

45. de Souza Costa CA, Hebling J, Hanks CT. Effects of light-curing time on the cytotoxicity of a restorative resin composite applied to an immortalized odontoblast-cell line. Oper Dent. 2003;28(4):365-70.

46. Tadin A, Galic N, Mladinic M, Marovic D, Kovacic I, Zeljezic D. Genotoxicity in gingival cells of patients undergoing tooth restoration with two different dental composite materials. Clin Oral Invest. 2014; 18:87-96.

47. Schweikl H, Spagnuolo G, Schmalz G. Genetic and cellular toxicology of dental resin monomers. J Dent Res. 2006;85(10):870-7.

48. Schatzle M, Loe H, Burgin W, Anerud A, Boysen H, Lang NP. Clinical course of chronic periodontitis. J Clin Periodontol. 2003; 30:887-901.

49. Soancă A, Lupse M, Moldovan M, Pall E, Cenariu M, Roman A, Tudoran $\mathrm{O}$, Surlin $\mathrm{P}$, Șorițău $\mathrm{O}$. Applications of inflammation-derived gingival stem cells for testing the biocompatibility of dental restorative biomaterials. Ann Anat. 2018;218:28-39.

50. Cândea Ciurea A, Şurlin P, Stratul ŞI, Soancă A, Roman A, Moldovan $\mathrm{M}$, et al. Evaluation of the biocompatibility of resin composite-based dental materials with gingival mesenchymal stromal cells. Microsc Res Tech. 2019;82(10):1768-78.

51. Hegde MN, Wali A. BisGMA and TEGDMA elution from two flowable nanohybrid resin composites: an in vitro study. British Journal of Medicine and Medical Research. 2015;5:1096-104.

52. Al-Hiyasat AS, Darmani H, Milhem MM. Cytotoxicity evaluation of dental resin composites and their flowable derivatives. Clinical Oral Investigations. 2005;9:21-25.

53. Schwendicke F, Göstemeyer G, Blunck U, Paris S, Hsu L-Y, Tu Y-K. Directly Placed Restorative Materials: Review and Network Meta-analysis. J Dent Res. 2016;95(6):613-22.

54. Kubo S, Yokota H, Yokota H, Hayashi Y. Three-year clinical evaluation of a flowable and a hybrid resin composite in non-carious cervical lesions. J Dent. 2010;38(3):191-200. 